\title{
UTILIZATION OF INDONESIAN SAGO HAMPAS WASTE FOR BIOHYDROGEN PRODUCTION: EFFECT OF DILUTE ACID PRETREATMENT
}

\author{
Khamdan Cahyari ${ }^{1}$, Utari Ervina Syafitri ${ }^{2}$, Errenita Putri $^{3}$ \\ Department. of Chemical Engineering, \\ Faculty of Industrial Technology, Universitas Islam Indonesia ${ }^{1,2,3)}$ \\ Jl. Kaliurang Km.14,5, Sleman, Yogyakarta, 55584 \\ E-Mail : khamdan.cahyari@uii.ac.id ${ }^{1}$
}

\begin{abstract}
ABSTRAK
Penelitian ini bertujuan untuk mengetahui produksi biohidrogen dari limbah sagu hampas di Indonesia terutama pada perlakuan pretreatment asam encer. Sampah sagu tersebut dihasilkan dari industri rumahan yang menghasilkan bubuk tapioka dari log Arengapinnata. Perlakuan pretreatment asam encer dilakukan dengan menggunakan asam sulfat (H2SO4) pada konsentrasi 0,27,3, dan 0,6 M dengan berbagai periode waktu paparan 30, 60 dan 90 menit. Setelah menyelesaikan pretreatment tersebut, sagu mengangkut limbah padat kemudian mengalami fermentasi gelap ar 30, 1 atm dan pH awal 5.0. Hasilnya menunjukkan bahwa total hasil gas berada pada kisaran 1 - $4 \mathrm{ml} / \mathrm{g} V S$. Konsentrasi H2 meningkat secara signifikan pada maksimum 27,7\% v. Hasil ini menunjukkan bahwa limbah sagu di Indonesia berpotensi menjadi sumber energi terbarukan biohidrogen.
\end{abstract}

Kata kunci : Biohidrogen, Sagu Hampas Limbah, Asam Encer, Konsentrasi, Fermentasi.

\section{INTRODUCTION}

Hydrogen is the cleanest energy carrier in future due to its superior properties. It emits less greenhouses gases, more energy efficient conversion up to $50 \%$, higher energy densities, and it is renewable. It can be produced from water electrolysis when there is sufficient free excess electricity from geothermal plant or else. But more promising one, that hydrogen can be generated from organic waste (Balat, 2008).

The generation of hydrogen using the waste is through dark fermentation process which empower microbial community to metabolize organic matter into volatile fatty acids along with electron transfer to hydrogenase to convert proton into hydrogen $\left(\mathrm{H}_{2}\right)$. This method is influenced by many factors e.g. temperature, $\mathrm{pH}$, substrate concentration, inhibitors, and reactor types (Arooj et al., 2008; Lee et al., 2010).
Sago hampas solid waste is one of the environmental problem from the activities of carbohydrate rich powder of Arengapinnata home industries located in many places in Indonesia. This solid waste is generally pilled out in river bank without any further treatment. A very little portion of the waste is used as co-substrate of cattle feed. In order to reduce such environmental problem, it was proposed to utilize the solid waste as raw material for biohydrogen production. However, the solid waste belongs to lignocellulose materials which are not suitable for direct consumption of fermentative microorganisms to produce biohydrogen. Therefore, it was also proposed to perform dilute acid pretreatment of the solid waste prior to subjected into dark fermentation. This research was meant to investigate the effect of dilute acid pretreatment toward biohydrogen yield of fermentative sago hampas waste. 


\section{MATERIALS AND METHODS \\ 2.1. Feedstock}

Sago hampas waste was collected from home industries area in Klaten, Middle Java, Indonesia. The solid waste was then pretreated using $\mathrm{H}_{2} \mathrm{SO}_{4}$ at various concentration $(0.2,0.3$ and $0.6 \mathrm{M})$ and various time of exposure $(30,60$ and 90 minutes). Having completed, the residual solid was dried in room temperature, thereafter called as feedstock.

\subsection{Inoculums}

Hydrogen producing microorganisms was originally from residual sludge of cow dung biogas plant which had been treated through $\mathrm{pH} 5.0$ (24 hours) and heat-shock treatment $\left(95^{\circ} \mathrm{C}, 45 \mathrm{~min}\right)$.

\subsection{Experimental Procedures}

To investigate the possibility to harvest $\mathrm{BioH}_{2}$ from sago hampas waste, a batch experiment was conducted using $120 \mathrm{ml}$ serum vial bottles as digesters. Each digester was filled out with $30 \mathrm{ml}$ inoculums, 6.1 gram feedstock, $10 \mathrm{ml}$ buffer solution
$\mathrm{NaHCO}_{3} 2$ Mand Distilled Water, thereafter closed and sealed with butyl rubber stopper and aluminum cap.

In order to provide anaerobic condition, the digester was then flushed with a gas mixture of $80 \% \mathrm{~N}_{2}$ and $\mathrm{CO}_{2}$ for 1 minute. Further, it is incubated at thermophilic $\left(30^{\circ} \mathrm{C}, 1\right.$ bar $)$ condition in incubator (Venticell, MMM Medenter Einrichtungen $\mathrm{GmbH}$, MMM-Group) for 7 days. Gas samples were taken from vials and injected to gas chromatography (GC) for analysis during the incubation time. Samples of residual liquid were taken for volatile fatty acid (VFA) analysis, $\mathrm{pH}$ and chemical oxygen demand (COD) measurement.

\subsection{Analysis}

Gas content was analyzed using Gas Chromatography which equipped with MS 5A column and TCD. TS, VS and ash were measured based on standard method of APHA.

\section{RESULTS AND DISCUSSION}

\subsection{Effect of Dilute Acid $\mathrm{H}_{2} \mathrm{SO}_{4}$ Concentration}

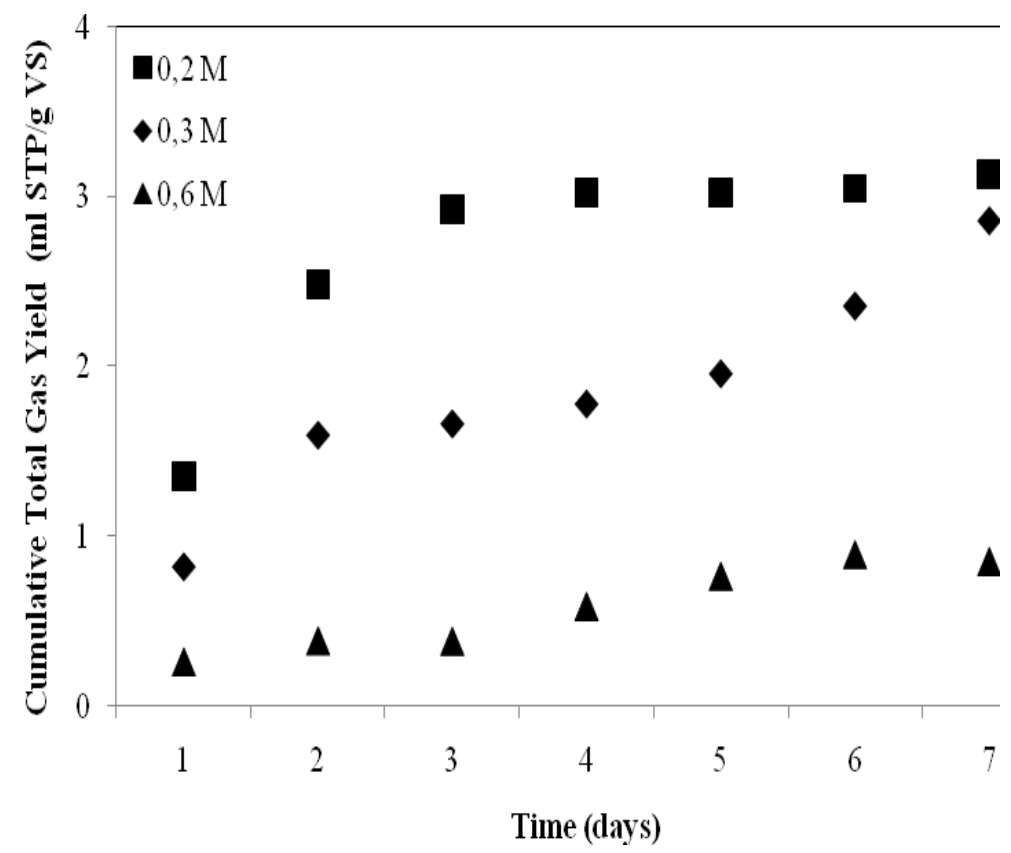

Figure. 1 Yield of Total Cumulative Gas at Various Concentration of Dilute Acid. 
Figure 1 shows that various concentration of dilute acid $\mathrm{H}_{2} \mathrm{SO}_{4}$ has significant effect towards total gas yield. Concentration of $0.2 \quad \mathrm{M} \quad \mathrm{H}_{2} \mathrm{SO}_{4}$ could generate higher total gas yield. It is noticed that the higher concentration of dilute acid, the lower total gas produced. This is due to destructive impact of the acids toward fermentable sugars which has been generated from hydrolysis of the lignocellulosic sago hampas.

\subsection{Effect of Time Expsosure}

Figure 2 shows cumulative total gas yield in the effect of time exposure of dilute acids pretreatment. the highest total gas yield was generated from 60 minutes dilute acids pretreatment. It is noticed at 30 minutes exposure time, there is little quantity of the sago hampas that has been hydrolyzed to produce fermentable sugars compare to of that 60 minutes. However, total gas yield was lower at time exposure of 90 minutes due to destructive impact of the acids toward fermentable sugars. It is therefore the yield turned to lower value. Hydrogen percentage was in the range between 16 to $27 \% \mathrm{v}$.

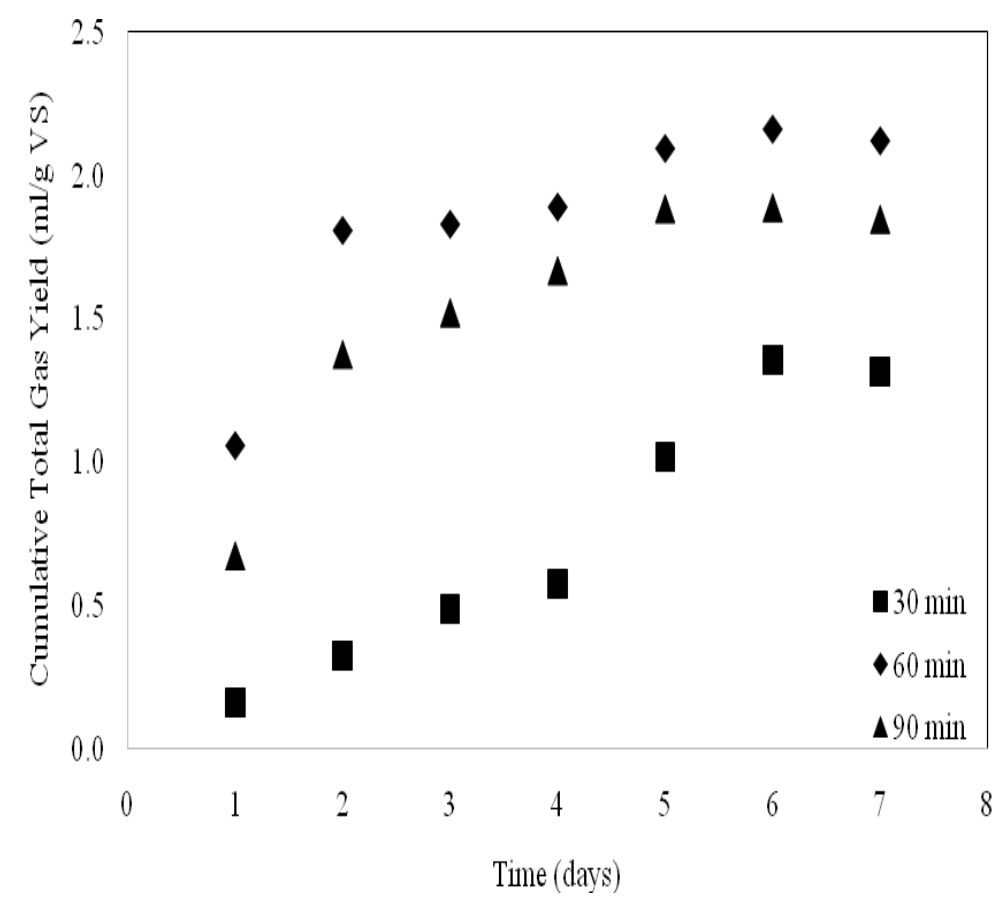

Figure. 2 Yield of Total Cumulative Gas at Various Time Exposure of Dilute Acid $\mathrm{H}_{2} \mathrm{SO}_{4} 0.3 \mathrm{M}$.

\section{CONCLUSION}

Production of biohydrogen from sago hampas waste of home industries in Indonesia can be solution of its environmental problem. In this result, the effect of dilute acids pretreatment was performed with result 60 minutes and $0.2 \mathrm{M}$ $\mathrm{H} 2 \mathrm{SO} 4$ generated the highest total gas yield. The percentage of hydrogen in total gas was in the range between 16 to $27 \% \mathrm{v}$ at yield $1-$ $4 \mathrm{ml} / \mathrm{g}$ VS. It shows that the sago hampas waste is suitable raw materials for production of renewable energy of biohydrogen.

\section{Acknowledgements}

Authors acknowledges the financial support of this research to Dept. of chemical and textile engineering, Faculty of Industrial Technology, Islamic University of Indonesia. 


\section{REFERENCES}

Andreas, B., Sárvári Horváth, I., Cahyari, K., Setiadi, T., 2011. Effects of Acid Pretreatment of Inoculums and Substrate Concentration for Batch Thermophilic Biohydrogen Production from Starch-Rich Synthetic Wastewater.

Arooj, M.F., Han, S.-K., Kim, S.-H., Kim, D.-H., Shin, H.-S., 2008. Continuous Biohydrogen Production In a CSTR Using Starch As a Substrate. Int. J. Hydrog. Energy 33, 3289-3294.

Balat, M., 2008. Potential Importance Of Hydrogen As A Future Solution To Environmental And Transportation Problems. Int. J. Hydrog. Energy 33, 4013-4029.

Lee, D.-Y., Ebie, Y., Xu, K.-Q., Li, Y.-Y., Inamori, Y., 2010. Continuous $H 2$ and $\mathrm{CH} 4$ Production From HighSolid Food Waste In The Two-Stage Thermophilic Fermentation Process With The Recirculation Of Digester Sludge. Bioresour. Technol. 101, S42-S47.

Turcot, J., Bisaillon, A., Hallenbeck, P.C., 2008. Hydrogen Production by Continuous Cultures of Escherchia Coli Under Different Nutrient Regimes. Int. J. Hydrog. Energy 33, 1465-1470. 